International Journal of Social Science And Human Research

ISSN(print): 2644-0679, ISSN(online): 2644-0695

Volume 04 Issue 06 June 2021

DOI: $10.47191 / \mathrm{ijsshr} / \mathrm{v} 4-\mathrm{i} 6-32$, Impact factor-5.586

Page No : 1449-1459

\title{
Gap Analysis and Determination of the Necessary Improvements in theProduction of the World-Class System (Case Study: Iran Khodro Raje)
}

\author{
Seyed Morteza Aghapour Miri ${ }^{1}$, Marzieh Amouei ${ }^{2}$, Omekolsoum Amouei $^{3}$ \\ ${ }^{1}$ School of Management, Nima Institute of Higher Education, Mahmoudabad, Iran \\ ${ }^{2}$ Faculty of Management and Accounting, Rah-e Danesh Non-Profit Higher Education Institute, Babol, Iran \\ ${ }^{3}$ Damavand Ershad Non-Profit Higher Education Institute, Tehran, Iran
}

\begin{abstract}
This article aims to investigate and identify gaps in the manufacturing system of world-class (WCM), In the auto industry and to establish the necessary adjustments to the systems in the organization using the critical performance analysis (IPA). This study presents a blend of the theoretical and practical framework as stated in the literature study and integrates the experts' viewpoints. The critical characteristics of Iran Khodro Company's world-class production system were defined. Then the essential elements for improving the company's world-class production system were defined and addressed utilizing critical performance analysis (IPA). Performance Analysis was used to acquire the gap analysis findings and identify areas for improvement (Importance performance analysis). Using this model system in world-class manufacturing in the Iran Khodro Company, assist the supreme managers and supervisors in identifying areas in the company that require improvement, and after implementing improvement measures in these areas, ensure the success of this system's establishment and ability to make the best decisions in the area of worldclass production. Without a doubt, this article will be one of the most effective techniques for determining and analyzing organizational improvements and the development and implementation of WCM. For the experts, there will be a plethora of options.
\end{abstract}

KEYWORDS: world-class manufacturing, DEMATEL, importance-performance analysis, essential points for improvement.

\section{1- INTRODUCTION}

World-class manufacturing is a crucial instrument for overcoming some of the most significant obstacles and impediments to entrance and survival in the global economy and expanding their potential forces. The discussion on globalization is one of the topics that has captivated the attention of our country's senior decision-makers to a significant extent nowadays. The necessity for globalization, particularly in the manufacturing sector, is becoming more apparent (Sobhanifar, 2004). Because of the importance of global competition, numerous challenges at the micro and macro levels of the organization have become more sensitive. Meanwhile, though many Iranian firms do not yet have the necessary circumstances for competitiveness, their participation in the international competition arena is not far off the horizon, given future developments. As a result, studying and studying issues in the dimensions of global competitiveness is critical. World-class production is an issue that is frequently discussed in today's competitive environment, international trade, and even Iranian companies, and it is of particular relevance in the theoretical and executive realms (Goodarzi, 2004). The significance of the current problem is the success of this system, and the rising competitiveness of Iran Khodro Company compared to its rivals.

The automobile industry is one of the most significant manufacturing areas in which considerable investments have been made. Manufacturing automobiles is an essential part of global trade and industry. According to surveys, the worldwide automobile sector employs approximately 58 million people (directly and indirectly), accounting for more than 5\% of all industrial employment, with a turnover of over 1.1 trillion dollars. In addition, the manufacture of almost 66 million cars in 2005 was one of the most significant operations and elements in the car manufacturing industry (Hosseini, 2007). This industry is referred to as the "industrial industry" by Peter Drucker. Over 5000 billion tomans have been spent on automobile production and over 200 component manufacturing firms in Iran (Sajjadi, 2007).

Iran Khodro has developed its scientific and research capabilities to become a world-class brand-owned car and has achieved the latest technologies in collaboration with reputable European companies. Still, global competition, rapid technology changes, and short life cycles have made it difficult to achieve this goal. They were responsible for the modern industrial industry's fierce competition. Companies have been forced to reassess their strategy due to a new competitive climate, continuously changing manufacturing and business standards (Sobhanifar 2006). This research aims to examine the gap and identify the areas in which the 

Study: Iran Khodro Raje)

world-class manufacturing system may be improved. We uncover the practical elements in assessing Iran Khodro Company's worldclass production and highlight the important sites for improvement in Iran Khodro Babol Company's world-class output in this study. Using the significance-performance analysis technique, this research seeks to analyze and identify gaps in the world-class production system (WCM) in the automobile sector and define the required areas for improving this system in the organization (IPA). The most significant indications in a world-class manufacturing system and how to build this system in Iran Khodro Company are discussed in this article and the gaps and areas for development.

\section{2- THEORETICAL FOUNDATIONS AND RESEARCH BACKGROUND}

\section{2-1-World class production}

World-class production, first coined by Hayes and Wilright in 1984, had appeared in several formulas as an extract from the ideas of Japanese production in the 1970s when Western production failed. And the inability to compete was perceived. Worldclass production was formulated and presented as a revolutionary business approach in the United States in the 1980s and the United Kingdom in the 1990s (Hooper et al., 2008). They were able to analyze and compare the methods used. German, American and Japanese companies state that world-class manufacturers need to improve in six areas to achieve a competitive advantage, including skills and abilities of the workforce, technical management capabilities, quality (as Competitive weapons), employee participation, restructuring in construction engineering, and an attitude of increasing improvement (Hayes and Wilright, 1984). The concept of world-class production was then expanded, embraced, and augmented by several authors, who reinforced some of Hayes' and Willerite ideas (Bariara, 1999). With his valuable work, World-Class Production, Richard Schoenberger has contributed to the development of this concept in the operational literature (Hosseini, 2007). Sch 1986nberger founded the World Class International Consulting Company (WCI) in 1986, operating in Europe and the United Kingdom in the late 1980s and 1990s. British customers include companies such as GlaxoS, Clarks Shoes, Cotts Villa and Midland Bank. The WCI's interpretation of WCM in the late 1990s stated that a world-class business was organized to serve the customer, but it had to go back to basics. That means continuous and rapid improvement in customer service through better quality, lower and faster costs, more flexibility and responsiveness. They emphasized how WCM techniques are integrated.

\section{2-2-World-class production definitions}

Unfortunately, there is no precise, accepted, and universal definition of world-class production (Kod Ali et al., 2004; Wang, 2001). Sharma (2005) states that if you are world-class, you are among the best in the world in your profession. World-class production is becoming the best in the world in a particular sector of the industry (Todd, 1995). Schنgnberger (1986) describes world-class production as methods for the slogans of the Olympic Games cities, Altius and forties that are faster, more and more powerful.

Table 1. Summarizes the research conducted in the world-class production model

\begin{tabular}{|l|l|l|l|}
\hline No. & Authors & Year & Summary of findings \\
\hline 1 & Riad Eid & 2009 & $\begin{array}{l}\text { General Model To implement world-class production, the model has two categories } \\
\text { of enablers that lead to success in WCM implementation; these two enablers include } \\
\text { WCM technical enablers and WCM strategic enablers. }\end{array}$ \\
\hline 2 & $\begin{array}{l}\text { Sangwan } \\
\text { and } \\
\text { Digalwar }\end{array}$ & 2008 & $\begin{array}{l}\text { Critical factor model for evaluating WCM systems has 12 crucial factors, including } \\
\text { management commitment, knowledge management, technology and innovation, } \\
\text { flexibility, quality, production control and planning, vendor management, customer } \\
\text { satisfaction and service, staff strengthening and training, Environmental safety and } \\
\text { health, cost, and company growth }\end{array}$ \\
\hline 3 & Cho & 2006 & $\begin{array}{l}\text { In the model, the first step to becoming a world-class manufacturer is to determine } \\
\text { the appropriate strategy. The following steps are to create a fundamental awareness } \\
\text { among all the factory factors. Then the use of uninterrupted production design } \\
\text { method requires multi-skilled staff and comprehensive productive maintenance, flat } \\
\text { production that requires reduced start-up time and traction system, and finally } \\
\text { standardization of operations that require error-free systems and Is automation. }\end{array}$ \\
\hline 4 & Farsijani & 1386 & $\begin{array}{l}\text { The organizational features development model facilitates the movement of Iranian } \\
\text { organizations to become a world-class producer, with three phases in each phase, } \\
\text { considers a series of essential features of world-class organizations and create them } \\
\text { in Traditional organization strives. }\end{array}$ \\
\hline
\end{tabular}



Study: Iran Khodro Raje)

\begin{tabular}{|c|c|c|c|}
\hline 5 & Sharma & 2005 & $\begin{array}{l}\text { He considers pure production to be necessary for achieving the desired results, } \\
\text { which he refers to as world-class production and considers pure production to be the } \\
\text { use of all appropriate methods, including } 5 \mathrm{~S} \text {, workplace cleanliness, etc. }\end{array}$ \\
\hline 6 & Eimani & 2006 & $\begin{array}{l}\text { The model states that to gain a competitive advantage and be considered a world- } \\
\text { class production, it proposes four optimization methods: total quality management, } \\
\text { comprehensive productive maintenance, lean manufacturing, and comprehensive } \\
\text { service management. }\end{array}$ \\
\hline 7 & $\begin{array}{l}\text { Safaei } \\
\text { Ghadikolaei }\end{array}$ & 1998 & $\begin{array}{l}\text { This model has seven phases to implement a world-class production system, } \\
\text { presenting a phased model of the world-class production system. }\end{array}$ \\
\hline 8 & Jelians & 1999 & $\begin{array}{l}\text { Extensive coverage of world-class organizations and the achievement of world-class } \\
\text { production position emphasize achieving world-class status in three stages: } \\
\text { predicting future events, the stage of preparation, and the stage of implementation. }\end{array}$ \\
\hline 9 & $\begin{array}{l}\text { Shafer and } \\
\text { Svald }\end{array}$ & 1996 & $\begin{array}{l}\text { The model considers the tools necessary to become a world-class producer of timely } \\
\text { production, productive maintenance, total quality management and employee } \\
\text { participation. }\end{array}$ \\
\hline 10 & MoTuani & 1994 & $\begin{array}{l}\text { Model } 5 \text { presents the key factors as the minimum world-class production } \\
\text { infrastructure: waste elimination, quality of vendors and suppliers, production and } \\
\text { production control, employee participation, exceptional attention to quality. }\end{array}$ \\
\hline 11 & $\begin{array}{l}\text { Him and } \\
\text { Campton }\end{array}$ & 1992 & $\begin{array}{l}\text { He introduces the operational principles of the organization, world-class production } \\
\text { organizations. Island knowledge of the parts of a production system and emphasis } \\
\text { on them has created a practical example. Also, a study presents the general principles } \\
\text { of effective improvement of production systems operations in ten principles. These } \\
\text { principles include long-term and medium-term goals, customer, organization, } \\
\text { employees, suppliers or vendors, management duty and commitment, performance } \\
\text { metrics, models, experience, technology. }\end{array}$ \\
\hline 12 & Gifi et al & 1990 & $\begin{array}{l}\text { The areas of productivity, strategy, management attitude, technology, organization, } \\
\text { performance measurement, human assets, quality and customer, are the main areas } \\
\text { in need of world-class production improvement. }\end{array}$ \\
\hline 13 & Huang & 1991 & $\begin{array}{l}\text { This model is based on four pillars: comprehensive quality control, timely } \\
\text { production, automation, and comprehensive maintenance. }\end{array}$ \\
\hline 14 & Ross & 1991 & $\begin{array}{l}\text { The role of information technology in creating alignment of the organization with } \\
\text { world-class production is crucial, and it is closely related to the cultural structure, } \\
\text { information flows, and human resources. }\end{array}$ \\
\hline 15 & $\begin{array}{l}\text { Haiz and } \\
\text { Wilright }\end{array}$ & 1984 & $\begin{array}{l}\text { World-class manufacturers need to improve six areas to achieve a competitive } \\
\text { advantage, including skills and competencies of the workforce, technical } \\
\text { management capabilities, quality (as a competitive weapon), employee } \\
\text { participation, restructuring in engineering Build and have an attitude of increasing } \\
\text { improvement. }\end{array}$ \\
\hline
\end{tabular}

\section{2-3 Significance-Performance (IPA) Technique}

Significance-Performance Analysis (IPA) derived from Importance-Performance Analysis is one of the methods of gap analysis. This technique was first introduced in 1977 by John Martila and John James. This technique is very close to the SERVQUAL technique in terms of the data collection method. Significance-Performance Analysis is an effective tool for assessing the organization's competitive position, identifying opportunities for improvement, designing marketing strategies and providing targeted service. For the first time, Marita and James presented a significance-performance analysis to identify and prioritize product or service features that an organization can focus on to maximize customer satisfaction. By forming a two-dimensional matrix whose vertical axis shows customers' perception of each feature's performance (quality) and its horizontal axis shows the importance of that feature in customer decision-making, practical suggestions can be provided to managers. This two-dimensional matrix is called the importance-performance matrix.

Because separate analysis of performance and significance dimension data, mainly when each data set is studied simultaneously, may not be meaningful, data on the level of significance and performance of the indicators on two-dimensional networks where the $\mathrm{y}$-axis indicates the significance dimension And the $\mathrm{X}$-axis indicates the performance dimension (Figure 1). 

Study: Iran Khodro Raje)

This two-dimensional network is called the significance/performance matrix or IP matrix. The role of the IP matrix, which is made up of four parts or quarters, and each strategy has a specific system in each quarter, is to help the decision-making process. This matrix is used to identify the priority of indicators for improvement.

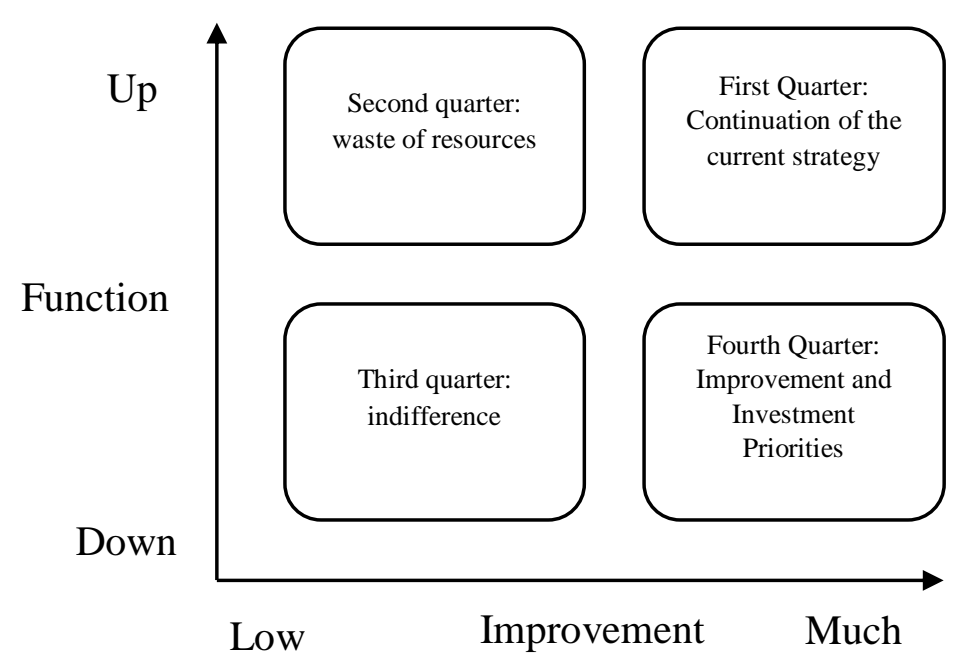

Figure 1 Matrix IPA

Based on how important each indicator is (optimal status) and how well the organization performs in this area (current position), four quarters can be identified:

Scope of indifference: low performance-low importance

Waste range: high performance - low cost

Weaknesses: Low performance-High importance

- Acceptable scope: high performance - high importance

The significant gap in the significance-performance analysis model is the second and fourth quarters. If most of the indicators are in the second quarter, the organization has invested in indicators that are not worth much. The performance in the field of insignificant indicators is high. If most of the indicators are in the fourth quarter, the organization has a weak performance in the field of great importance. The organization's strategy should be to first transfer the elements from the fourth quarter to the first quarter and remove all the details of the second and third quarters.

A significance-performance analysis is very suitable for SERVQUAL analysis and competitive analysis. To perform this analysis, like other methods of gap analysis, the paired t-test can be used. A questionnaire with a range of 5, 7, or 9 is typically used to collect data. There are two types of questions for each indicator. A question that assesses the current situation and a question that sets the desired position.

According to the above information, the step-by-step method of significance-performance analysis is as follows. Step one:

First, identify and extract the quality characteristics that play a role in the quality of services. Step two:

Specify the degree of importance of service quality characteristics and the degree of performance of the quality characteristic $(\mathrm{P}=1,2, \ldots \ldots . \mathrm{n}$ and $\mathrm{J}=1,2, \ldots \ldots \mathrm{m})$, respectively. Value donors are values and performance values specified for the $\mathrm{j}$ attribute by the decision-maker or the client. These values are determined using the Likert spectrum. In this case, it is clear that $1 \leq$ bjp, cjp or5 or $1 \leq$ are bjp, cjp $\leq 7$.

Step three:

Use the geometric mean and integrate the opinions of all decision-makers or customers. Saati suggests that using the geometric mean to express the collective opinion of several decision-makers is a more effective solution. Quality of service is called the result of the collective view of the customer or expert.

$$
c_{j}=\left(\prod_{i=1}^{n} c_{j p}\right)^{1 / n} \quad, \quad b_{j}=\left(\prod_{i=1}^{n} b_{j p}\right)^{1 / n}
$$

Thus, each qualitative characteristic (jm) has a degree of importance and a degree of performance. 
Step 4:

Calculate the threshold value. The threshold value is used to determine the IPA matrix cells. An arithmetic mean is used to determine the threshold value. The significance threshold value and the performance threshold value are denoted by $\mu \mathrm{b}$ and $\mu \neg \mathrm{c}$, respectively.

$$
\mu_{b}=\frac{\sum_{j=1}^{m} b_{j}}{m}, \quad \mu_{c}=\frac{\sum_{j=1}^{m} c_{f}}{m}
$$

Step 5:

$\mathrm{M}$ is the number of quality characteristics to measure the quality of services.

Specify the relative position of each service quality characteristic on the IPA matrix.

Note that $\mu \mathrm{b}$ and UC will not necessarily be in the middle.

Step 6:

Discovering the customer's voice helps to gain the weight of the customer's wishes. According to Wu et al., The gap between the value of significance and the performance of the $\mathrm{j}$-characteristic multiplied by the value of its importance can indicate the weight of the qualitative characteristic of the $\mathrm{j}$-th. We denote the weight of the j-characteristic by owj.

$$
O W_{j}=\left|\left(b_{j}-c_{j}\right) \times b_{j}\right|
$$

To make the analysis more accessible, we normalize it as follows.

$$
s w_{j}=\frac{o w_{j}}{\sum_{j=1}^{m} o w_{j}} \quad, 0 \leq s w_{j} \leq 1, \sum_{j=1}^{m} s w_{j}=1
$$

Now features that have more swj should be given higher priority for improvement.

\section{3- RESEARCH MODEL}

As mentioned earlier, Sanguan and DeGalvar (2008) study introduced 12 critical factors to evaluate world-class systems. These 12 crucial factors include top management commitment (TM), knowledge management (KM), technology and innovation. (IT), Flexibility (FX), Quality (QC), Production Control and Planning (PPC), Vendor Management (VM), Customer Satisfaction and Service (CSS), Employee Empowerment and Training (ETE), Environmental Safety and Health (EHS), Cost (CST), and Corporate Growth (CG) are the critical factor models for evaluating the world-class production systems presented by Sanguan and Digalvar as shown in Figure 2 and Table 2:

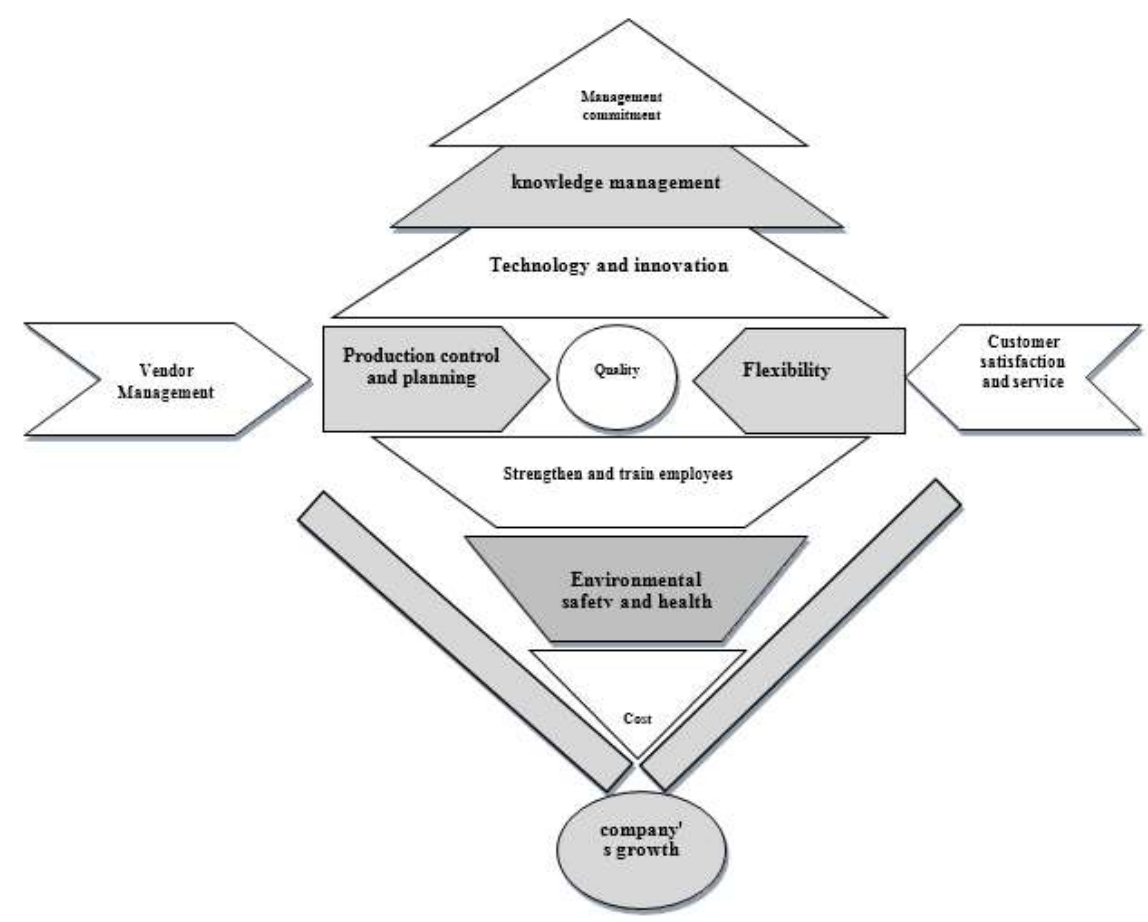

Figure 2. Sanguan and Digalvar models (2008) 

Study: Iran Khodro Raje)

Table 2 Sub-criteria of the research model

\begin{tabular}{|c|c|c|}
\hline No. & Critical factor & Performance variable \\
\hline 1 & $\begin{array}{l}\text { Top management } \\
\text { commitment }\end{array}$ & $\begin{array}{l}\text { Resource allocation, change planning, process monitoring, participation in } \\
\text { strategic quality management }\end{array}$ \\
\hline 2 & $\begin{array}{l}\text { Strengthen and } \\
\text { train employees }\end{array}$ & $\begin{array}{l}\text { Repetition (continuity) of training and retraining - In-company training with an } \\
\text { in-house trainer (including on-the-job training) - In-company training with an } \\
\text { out-of-company instructor - Total cost of training - Identification of training } \\
\text { needs - Employee satisfaction with total training - Authorized Workers to review } \\
\text { their work - Encourage workers to solve problems - The amount of task force } \\
\text { employed. }\end{array}$ \\
\hline 3 & $\begin{array}{l}\text { knowledge } \\
\text { management }\end{array}$ & $\begin{array}{l}\text { Access to knowledge management resources - Appropriate organizational } \\
\text { culture for knowledge management - Employee willingness to share knowledge, } \\
\text { information, communication and technology (ICT) used in knowledge } \\
\text { management - Number of knowledge items helped to solve problems - } \\
\text { Knowledge management assistance to reduce time Delay / Response, Reduction } \\
\text { in process turnover rejection - Reduction in new product development cycle time } \\
\text { with knowledge management - Presentations, conferences, negotiations, etc. that } \\
\text { help to create new knowledge. }\end{array}$ \\
\hline 4 & $\begin{array}{l}\text { Innovation } \\
\text { technology }\end{array}$ & $\begin{array}{l}\text { Development in the manufacturing process - Reduction of manufacturing } \\
\text { latency - Development of new (innovative) products - Production of products } \\
\text { that work only in the native environment. }\end{array}$ \\
\hline 5 & $\begin{array}{l}\text { Environmental } \\
\text { safety and health }\end{array}$ & $\begin{array}{l}\text { Investing in safety (safety training budget) - Communication levels in the field } \\
\text { of security and health issues - Clarity in discipline policies - Organization for } \\
\text { safety (control, communication, cooperation and competition) - Safety and } \\
\text { health auditing - Committee meetings Employee safety - Workforce } \\
\text { participation and top management in safety and health - Testing employees' } \\
\text { knowledge of health and safety policies. }\end{array}$ \\
\hline 6 & Quality & $\begin{array}{l}\text { System development and quality policies - Reliability, reliability and } \\
\text { functionality of the product related to competitors - Estimated percentage of } \\
\text { satisfied customers - Quality stability - Effectiveness of the system in identifying } \\
\text { defective products. }\end{array}$ \\
\hline 7 & Cost & $\begin{array}{l}\text { Product cost and process redesign - Costs related to material handling, } \\
\text { distribution and warehousing - After-sales service costs (warranty) - Reduction } \\
\text { in information maintenance costs - Facility maintenance costs (equipment } \\
\text { failure or failure cost, cost of Equipment failure, cost of repairs, and rework, cost } \\
\text { of spare parts inventor). }\end{array}$ \\
\hline 8 & $\begin{array}{l}\text { Planning and } \\
\text { production control }\end{array}$ & $\begin{array}{l}\text { Efficient/preventive maintenance rate - Stability of production schedule - } \\
\text { Degree of process automation - Number of executed Kaizens. }\end{array}$ \\
\hline 9 & $\begin{array}{l}\text { Vendor } \\
\text { Management }\end{array}$ & $\begin{array}{l}\text { Selection of suppliers based on quality about price or schedule - Completion of } \\
\text { supplier rating system - Expansion of long-term contracts with suppliers - } \\
\text { Clarity of specifications set for suppliers - Response of suppliers to requests for } \\
\text { changes - Communication with suppliers. }\end{array}$ \\
\hline 10 & Flexibility & $\begin{array}{l}\text { Fluctuations that occur in quality with changes in volume or composition of the } \\
\text { product - Fluctuations that occur in cost with changes in volume or arrangement } \\
\text { of the product - Fluctuations that occur in delivery performance with changes in } \\
\text { volume or composition of the product - The use of electronic procurement - Use } \\
\text { of IT tools - The use of multi-purpose tools. }\end{array}$ \\
\hline
\end{tabular}



Study: Iran Khodro Raje)

\begin{tabular}{|l|l|l|}
\hline 11 & company's growth & $\begin{array}{l}\text { Profitability - Increasing market share - Organizational reputation in the market } \\
\text { - Increasing the number of customers. }\end{array}$ \\
\hline 12 & $\begin{array}{l}\text { Customer } \\
\text { satisfaction } \\
\text { service }\end{array}$ and & $\begin{array}{l}\text { Customers with interaction / potential customers - feedback on quality, delivery } \\
\text { and price-performance - meeting customer needs - customer satisfaction with } \\
\text { the product (characteristics, quality, cost, durability and reliability - sales } \\
\text { (auction) at the customer's suggestion - quality and Customer service process - } \\
\text { Knowledge of customer service, skills and attitudes - Time to send (transfer) } \\
\text { problems to staff who need to solve them in the best way - Use of ICT for } \\
\text { customer service - Technical support provided to the customer. }\end{array}$ \\
\hline
\end{tabular}

According to the model presented in the current research, the question now is how to determine the necessary points for improving Iran Khodro Babol Company in world-class production?

This question will be answered in the following sections.

\section{4- METHODOLOGY}

Analysis of research data and findings

Localization of indicators

Identify and evaluate effective criteria

To identify the effective criteria in world-class production, Sanguan and Digalvar (2008) article have been used, and the extracted criteria have been fully mentioned. Because the number of identified criteria is high, to Localization of standards and determination of essential criteria about the current research, the Delphi hourly method has been used. A questionnaire has been provided to the experts.

This questionnaire is qualitatively based on a 10-point spectrum from completely unimportant to completely important. After collecting and screening, and determining the essential criteria and characteristics, the Delphi technique performs calculations with software help. EXCEL is done.

After calculations and data output from EXCEL software, the indicators that after aggregation of experts' views and arithmetic mean were slightly higher than the threshold value of 0.7 were confirmed.

The results of screening and determining the degree of importance of the indicators were re-examined by experts. Finally, 12 indicators were identified as the leading indicators and were selected as the main criteria for the final solution of the model. Table 3 is the leading indicators of world-class production.

Table 3. Importance of critical indicators

\begin{tabular}{|l|l|}
\hline Critical factor & Importance of key indicators \\
\hline Quality & 0.98 \\
\hline Innovation technology & 0.94 \\
\hline Company's growth & 0.94 \\
\hline Flexibility & 0.87 \\
\hline Customer satisfaction and service & 0.82 \\
\hline Strengthen and train employees & 0.81 \\
\hline Planning and production control & 0.77 \\
\hline Cost & 0.75 \\
\hline Environmental safety and health & 0.742 \\
\hline Vendor Management & 0.74 \\
\hline Top management commitment & 0.72 \\
\hline
\end{tabular}


Gap Analysis and Determination of the Necessary Improvements in the Production of the World-Class System (Case Study: Iran Khodro Raje)

\begin{tabular}{|l|l}
\hline Knowledge management & 0.72
\end{tabular}

Table 4. Importance of sub-indicators

\begin{tabular}{|c|c|c|c|}
\hline Sub-index & Score & Sub-index & Score \\
\hline $\begin{array}{l}\text { Organizational } \\
\text { reputation in the market }\end{array}$ & 0.942 & Policies of order & 0.728 \\
\hline $\begin{array}{l}\text { Development in the } \\
\text { manufacturing process }\end{array}$ & 0.914 & Educational needs & 0.728 \\
\hline $\begin{array}{l}\text { Increase the number of } \\
\text { customers }\end{array}$ & 0.914 & Safety and health audit & 0.728 \\
\hline Increase market share & 0.9 & $\begin{array}{l}\text { Time to send customer } \\
\text { problems }\end{array}$ & 0.728 \\
\hline Profitability & 0.871 & $\begin{array}{l}\text { Delivery and price- } \\
\text { performance }\end{array}$ & 0.728 \\
\hline Stability in quality & 0.825 & Retraining & 0.714 \\
\hline $\begin{array}{l}\text { Workers' authority to } \\
\text { review }\end{array}$ & 0.814 & The total cost of training & 0.714 \\
\hline $\begin{array}{l}\text { Respond to customer } \\
\text { needs }\end{array}$ & 0.814 & Labour force participation & 0.714 \\
\hline Select suppliers & 0.8 & Supplier completion & 0.714 \\
\hline Resource allocation & 0.8 & Participation in management & 0.714 \\
\hline System effectiveness & 0.8 & Reduce latency & 0.714 \\
\hline $\begin{array}{l}\text { Production program } \\
\text { stability }\end{array}$ & 0.775 & $\begin{array}{l}\text { Communication with the } \\
\text { supplier }\end{array}$ & 0.712 \\
\hline $\begin{array}{ll}\text { Reduce } & \text { product } \\
\text { development } & \end{array}$ & 0.771 & Supplier response & 0.7 \\
\hline Encourage workers & 0.757 & Quality policies & 0.7 \\
\hline $\begin{array}{l}\text { Percentage of satisfied } \\
\text { customers }\end{array}$ & 0.757 & teamwork & 0.7 \\
\hline Reliability, reliability & 0.737 & Feedback on quality & 0.7 \\
\hline Process monitoring & 0.728 & Satisfaction with education & 0.642 \\
\hline
\end{tabular}

Table 3 is about the importance of the leading indicators that the experts scored, and because all the leading indicators were above the threshold of 0.7 , all of them have been accepted. Table 4 deals with the importance of sub-indicators that experts scored, and because all major indicators were above the threshold of 0.7 , all of them have been accepted. A total of 34 factors with a score higher than 0.7 were selected. 

Study: Iran Khodro Raje)

\section{Gap analysis and determination of essential points for improvement}

After aggregating the views and getting the threshold of the final IPA table, each factor is drawn according to the characteristics determination table, according to the techniques and stages of the significance-performance model technique to establish the improvement points in this approach. The points in the second and fourth quarters of this chart are the points of progress, according to the sketching and placement of each element in one of the four quadrants of the graph. Similarly to the issues in the second quarter, the organization should increase its attention on that point, but the variables in the fourth quarter of the chart squander the company's resources; thus, the organization should concentrate on them.

In this study, according to the nature of the subject and its techniques, a questionnaire was used to collect data by field survey and survey of experts. To identify the practical characteristics of world-class production, research conducted in scientific articles, similar studies, and interviews with experts identified in previous stages have been used.

\section{A step-by-step method for IPA}

First, we identify and extract the quality characteristics that play a role in the quality of services according to the critical and practical criteria shown in Table 3. To 7 experts, a questionnaire containing each of these factors' importance and performance were given. Experts' opinions were asked about the organization's critical instead of how these factors are implemented. Experts rated these factors on a scale of 1 to 5 (very low to very high).

After summarizing the opinions and determining the status of the characteristics of the main factors of the experts, the threshold for the sum of these factors was selected, which is indicated by the Latin word and abbreviation.

Table 5. aggregation of expert opinions

\begin{tabular}{|l|l|l|l|l|l|}
\hline Critical factor & $\begin{array}{l}\text { Importance of } \\
\text { key indicators }\end{array}$ & Performance & Critical factor & $\begin{array}{l}\text { Importance of } \\
\text { key indicators }\end{array}$ & Performance \\
\hline $\begin{array}{l}\text { Top management } \\
\text { commitment }\end{array}$ & 2.9 & 2.78 & Flexibility & 4.36 & 1.57 \\
\hline Knowledge management & 2.9 & 3.02 & $\begin{array}{l}\text { Customer satisfaction } \\
\text { and service }\end{array}$ & 4.05 & 2.37 \\
\hline Innovation technology & 4.36 & 1.57 & $\begin{array}{l}\text { Strengthen and train } \\
\text { employees }\end{array}$ & 3.07 & 3.55 \\
\hline Vendor Management & 2.37 & 3.82 & $\begin{array}{l}\text { Environmental safety } \\
\text { and health }\end{array}$ & 2.03 & 3.44 \\
\hline $\begin{array}{l}\text { Planning and production } \\
\text { control }\end{array}$ & 3.2 & 3.2 & Cost & 3.2 & 2.03 \\
\hline Quality & 4.09 & 1.91 & Company's growth & 4.54 & 1.51 \\
\hline
\end{tabular}

After collecting opinions from experts, a geometric mean was taken, and the results of each were given in Table 5 to determine the status of the characteristics in the significance-performance diagram. In the next step, the threshold was obtained for each of the attributes of importance and performance, which sets the point of importance bu and the version with $\mu \mathrm{c}$.

\section{5- DISCUSSION AND CONCLUSION}

Given that the primary gap is between the model of significance-performance analysis in the second quarter and Jaharm, now the features in the fourth quarter, i.e. the organization has concentrated and spent on indicators that aren't worth much. High performance in the realm of trivial indicators) and waste of resources. Indicators of great relevance that exist in the second quarter, on the other hand, show that the firm or organization is performing poorly regarding these variables. According to the graph, the second quarter (focus) and the fourth quarter (waste of resources) are the points of improvement. This indicates that to progress, the company must pay attention to the elements in these two places. Table 6 lists the issues that the organization should pay more attention to or focus on and the points that the company should pay less attention to or focus on since they are squandering organizational resources.

Table 6. points of improvement in the significance-performance analysis model

\begin{tabular}{|l|l|}
\hline The first category (focus) & $\begin{array}{l}\text { The second category (waste of } \\
\text { resources) }\end{array}$ \\
\hline company's growth & Vendor Management \\
\hline Flexibility & Safety and health \\
\hline Technology and innovation & Knowledge management \\
\hline
\end{tabular}



Study: Iran Khodro Raje)

\begin{tabular}{|l|l|}
\hline Quality & Management commitment \\
\hline Customer satisfaction and service & \\
\hline
\end{tabular}

According to the indicators mentioned in Table 6, the importance of improving each of the indicators in the importanceperformance analysis model has been determined according to the OWJ and FWJ formulas, which are categorized and prioritized, respectively.

Table 7. The importance of improving the characteristic at the gap point

\begin{tabular}{|l|l|l|l|l|l|}
\hline $\begin{array}{l}\text { Management } \\
\text { commitment }\end{array}$ & 0.33 & $\begin{array}{l}\text { Vendor } \\
\text { Management }\end{array}$ & 3.44 & $\begin{array}{l}\text { Customer } \\
\text { satisfaction and } \\
\text { service }\end{array}$ & 6.78 \\
\hline $\begin{array}{l}\text { knowledge } \\
\text { management }\end{array}$ & 0.35 & Quality & 8.88 & $\begin{array}{l}\text { Safety and } \\
\text { health }\end{array}$ & 2.87 \\
\hline $\begin{array}{l}\text { Technology and } \\
\text { innovation }\end{array}$ & 12.15 & Flexibility & 12.15 & $\begin{array}{l}\text { Company's } \\
\text { growth }\end{array}$ & 13.78 \\
\hline
\end{tabular}

The qualities with the most SWJ, on the other hand, should be given more priority for improvement. Factors to consider: 1 - Business expansion 2- Innovation and technology 3- Adaptability 4- Quality 5- Customer satisfaction and service 6- Managing the seller 7 Health and safety 8- Management of information 9- The importance of management commitment was identified a top objective for improvement.

According to Riyad Eid (2009), manufacturing plants must understand "factors influencing the successful implementation of production in the world in developing countries, the case study of Egypt" in an article titled "Factors influencing the successful implementation of production in the world in developing countries, the case study of Egypt." Seven essential elements are categorized into two groups regarding the application and implementation of wcm methods. 1- Management commitment is the first category. 2- Quality Assurance Department, The second group, comprises 1- Supply chain, 3- Continuous Improvement, and 4Customer Participation. 2- Technical capability management 3- Production facility management.

According to the current study, the variables are now focused on the friend and resource waste is split, which is quite similar to Riyad Eid's first category in terms of substance. The Riyad Eid model is identical in terms of managerial dedication, quality, satisfaction, and customer service. The technique for collecting these variables, however, has been varied. Sanguan and Degalwar et al. (2015) have started performance modelling. They have produced an article entitled "Modeling production performance in the world-class" in their most recent paper in 2015 on performance and implementation of WCM in the organization. This work introduces 16 primary criteria and 172 sub-criteria comparable to the prior model utilized in this study. Sanguan et al., on the other hand, in this paper. Important factors and Important are the commitment of senior management, knowledge management, staff training, innovation, and technology, which are placed above other factors as essential factors using the ISM method, which is similar to the current research, with the difference that these factors in the recent study were identified as gaps and Improvement points and the IPA method was used to identify these factors.

\section{REFERENCES}

1) Sobhanifar, Yaser., 2005, World Class Production, Tadbir Magazine, No. 157. pp. 1-5.

2) Farsijani, Hassan., 2005, Challenges of product production in the world-class, Tadbir Magazine, No. 155, pp. 12-27

3) Farsijani, Hassan., 2007, World Class of Organizations and Total Quality Management, Tehran: Iran Industrial Training and Research Center.

4) Safaei Ghadiklaei, Abdolhamid., 1999, Principles of using production globally in car companies, PhD thesis, Tarbiat Modares University.

5) Goodarzi, Gholamreza., 2004, Designing the strategic decision model of a supply chain of components in production dimensions on a global scale, $\mathrm{PhD}$ thesis, Tarbiat Modares University.

6) Hayes, R.H., Wheelwright, S, C., (1984), Restoring our competitive edge: competing through manufacturing. Wiley, New York.

7) Lind, Johnny, (2001), "Control in world-class manufacturing- A longitudinal case study", management accounting research, 12, 41-74.

8) Kodali, R., Sangwan, K.S. \& Sunnapwar, V.K,(2004), "Performance Value analysis for the justification of world-class manufacturing system", Journal of Advanced Manufacturing Systems, Vol. 3, No. 1, pp. 85-102. 

Study: Iran Khodro Raje)

9) Digalwar, A.K. and Metri, B.A. (2005), "Performance measurement framework for world-class manufacturing", International Journal of Applied Management \& Technology, Vol. 3, No. 2, pp.83-102.

10) Digalwar, A.K. \& Sang wan, K.S., 2007, "Development \& validation of performance measures for World-class manufacturing practice in India". Journal of manufacturing systems, vol. 6, No, 1, pp. 21-38.

11) Hopper, Trevor. Jazayeri, Mostafa., Chris, Westrupt., (2008), "World-class manufacture and accountability (how companies and the state aspire to competitiveness)", Journal of accounting and organizational change, Vol 4, No 2, pp 97135.

12) Sangwan K.S. and Digalwar A.K., (2008), "Evaluation of world-class manufacturing systems: a case of Indian automotive industries", Int. J. Services and Operations Management, Vol. 4, No. 6.

13) Eid, R., (2009), Factors affecting the success of world-class manufacturing implementation in less developed countries, The case of Egypt, Journal of Manufacturing Technology Management, Vol. 20 No. 7. 